JIPS, Vol. 2 No. 1

Halaman: 40 - 51

Mei 2021

\title{
Peningkatan Hasil Belajar Daring Mapel IPS Melalui Model Pembelajaran Artikulasi Pada Peserta Didik SMP 20 Kota Semarang
}

\author{
Lucy Fiventina \\ SMP Negeri 20 Semarang \\ Lucy@gmail.com
}

\begin{abstract}
Abstrak
Latar belakang masalah penelitian ini adalah pembelajaran dengan hasil kurang dan partisipasi mengikuti pelajaran rendah, kurang antusias, siswa kurang aktif dan lebih cenderung pasif, permasalahan dalam penelitian ini adalah 1.Bagaimana aktivitas guru dengan menerapkan model pembelajaran artikulasi pada hasil belajar daring mata pelajaran IPS materi mengenal negara negara Asean peserta didik kelas VIII SMP 20 kota Semarang? 1.Untuk mengetahui aktivitas guru dengan menerapkan model pembelajaran artikulasi pada hasil belajar daring mata pelajaran IPS materi mengenal negara negara Asean peserta didik kelas VIII SMP 20 kota Semarang.Penelitian ini termasuk jenis penelitian tindakan kelas. Subyek penelitian siswa kelas VIII SMP N 20 Kota Semarang yang berjumlah 32 siswa. Model yang digunakan adalah model pembelajaran artikulasi dengan materi mengenal Negara Negara Asean. Hasil penelitian ini menunjukkan proses belajar-mengajar denagn model pembelajaran artikulasi dengan materi mengenal Negara Negara Asean meningkat dari siklus I dan siklus II, terbukti dari Siklus I rata-rata aktivitas siswa mencapai $67 \%$, siklus II mencapai $86.25 \%$, sehingga terjadi peningkatan sebesar $29.8 \%$. Siklus I nilai ketuntasan sebesar $6.25 \%$ dan pada siklus II meningkat menjadi 96.80\% sehingga terjadi peningkatan sebesar $90.55 \%$ Peningkatan hasil belajar siswa terjadi setelah dilakukan perbaikan siklus I dan siklus II disebabkan metode dan media yang digunakan guru/peneliti saat mengajar daring dengan sangat tepat. Penelitian yang dilakukan hanya sampai siklus II dan tidak dilanjutkan lagi karena sesuai dengan standar ketuntasan peneliti yaitu $80 \%$ itu dikatakan berhasil apabila siswa sudah memenuhi nilai ketuntasan 70.
\end{abstract}

Kata kunci : Daring.model artikulasi

\section{Abstract}

The background of this research problem is learning with less results and low participation in lessons, less enthusiasm, less active students and more likely to be passive. know the Asean countries students of class VIII SMP 20 Semarang city? 1. To find out the teacher's activities by applying the articulation learning model to the online learning outcomes of the social studies subject, the subject of knowing the Asean countries, students of class VIII SMP 20 Semarang city.This research is a classroom action research. The subjects of the research were 32 students of class VIII SMP N 20 Semarang City. The model used is the articulation learning model with material to know Asean countries.The results of this study indicate the teaching and learning process with the articulation learning model with the material of knowing Asean Countries increased from cycle I and cycle II, as evidenced by the average activity of Cycle I reached $67 \%$, cycle II reached $86.25 \%$, resulting in an increase of 29.8. \%. In the first cycle the completeness value was $6.25 \%$ and in the second cycle it increased to $96.80 \%$ so that there was an increase of $90.55 \%$ The increase in student learning outcomes occurred after improvements in cycle I and cycle II were made due to the very precise methods and media used by teachers / researchers when teaching online. The research was carried out only until cycle II and was discontinued because it was according to the researcher's completeness standard, namely $80 \%$, it was said to be successful if the student had met the completeness score of 70 .

Keywords: online, articulation model

\section{PENDAHULUAN}

Melalui Surat Edaran Mendikbud nomor 4 tahun 2020 tentang Pelaksanaan Kebijakan Pendidikan dalam Masa darurat Penyebaran Corona virus Disease (covid-2019), Mendikbud menjelaskan aturan lebih rinci tentang pon-poin pembelajaran jarak jauh. Dalam poin 2 surat edaran tersebut dijelaskan, proses belajar dari rumah dilaksanakan dengan ketentuan sebagai berikut: Belajar 
dari Rumah melalui pembelajaran daring/jarak jauhdilaksanakan untuk memberikan pengalaman belajar yang bermakna bagi peserta didik, tanpa terbebani tuntutan menuntaskan seluruh capaian kurikulum untuk kenaikan kelas maupun kelulusan. Belajar dari Rumah dapat difokuskan pada pendidikan kecakapan hidup antara lain mengenai pandemi Covid-19. Aktivitas dan tugas pembelajaran Belajar dari Rumah dapat bervariasi antarpeserta didik, sesuai minat dan kondisi masing-masing, termasuk mempertimbangkan kesenjangan akses/ fasilitas belajar di rumah. Bukti atau produk aktivitas Belajar dari Rumah diberi umpan balik yang bersifat kualitatif dan berguna dari guru, tanpa diharuskan memberi skor/ nilai kuantitatif.

Keberhasilan belajar pada setiap jenjang sekolah dipengaruhi oleh beberapa faktor. Tidak tepatnya guru dalam menggunakan model pembelajaran juga akan sangat mempengaruhi keberhasilan pembelajaran yang diharapkan. Guru hendaknya menyajikan materi dengan model pembelajaran dan model pembelajaran yang bervariasi dengan dibantu media yang tepat sehingga pembelajaran menjadi menarik dan tidak membosankan (Kasmadi, 1996:9). Permasalahan tersebut dapat terjadi karena guru kurang variatif dalam memakai model pembelajaran pembelajaran. Permasalahan di atas dapat diatasi dengan ditetapkan penggunaaan model pembelajaran-model pembelajaran pembelajaran yang sesuai kebutuhan. Penggunaan model pembelajaran pengajaran yang tepat untuk pelajaran IPS terutama materi Negara Asean akan dapat mendorong minat peserta didik dalam ketertarikan peserta didik dalam belajar IPS, yang akhirnya akan berpengaruhi terhadap hasil belajar peserta didik.

Dalam implementasi menghadapi pandemi covid 19 di SMP 20 kota Semarang sudah menyikapi dan memanfaatan pembelajaran jarak jauh dalam pembelajaran melalui berbagai media/fitur yang sudah disediakan baik melalui android atau fitur dari berbagai media sosial lainnnya. Guru sebagai salah satu faktor penentu keberhasilan sebuah pembelajaran. Guru mempunyai keterlibatan langsung baik secara emosi maupun pemikiran dengan peserta didik. Guru perlu mengadakan pembaharuan yang disesuaikan dengan perkembangan zaman dalam membelajarkan peserta didik agar dapat belajar dengan nyaman dan menyenangkan. Guru dapat diharapkan dapat menjadi factor penggerak yang membangkitkan semangat dan minat belajar peserta didik, oleh karena itu mempunyai wewenang untuk menentukan cara atau model pembelajaran yang dianggap paling tepat dan efektif untuk membelajarkan peserta didik. Guru juga diharapkan dapat menciptakan suasana belajar yang menyenangkan tetapi bermanfaat bagi peserta didik dan lebih menekankan keterlibatan peserta didik secara optimal dalam proses pembelajaran.

Salah satu model pembelajaran yang dilaksanakan oleh guru IPS dalam mengatasi masalah yang ada di SMP 20 kota semarang peneliti yang juga guru IPS menggunakan model pembelajaran pembelajaran kooperatif. Model pembelajaran pembelajaran kooperatif yang di dalamnya mengandung saling ketergantungan positif di antara peserta didik untuk mencapai tujuan pembelajaran. Setiap peserta didik mempunyai kesempatan yang sama untuk sukses. Aktivitas belajar berpusat pada peserta didik dalam bentuk diskusi, mengerjakan tugas bersama, saling membantu dan saling mendukung dalam memecahkan masalah. Melalui interaksi belajar yang efektif peserta didik 
lebih termotivasi, percaya diri, mampu menggunakan strategi berpikir tingkat tinggi, serta mampu membangun hubungan interpersonal.

Kenyataan yang ada khususnya mata pelajaran IPS pada materi mengenal negara negara Asean masih banyak peserta didik kurang mampu dalam menyerap penjelasan yang diberikan oleh guru hal ini ditunjukan hasil nilai harian yang masih dibawah KKM. Untuk mengatasi permasalahan tersebut peneliti akan menggunakan model pembelajaran yang tepat dalam meningkatkan pemahaman konsepkonsep materi pembelajaran khususnya mengenal negara negara Asean. Model pembelajaran kooperatif yang tepat diterapkan dalam pembelajaran pemahaman konsep adalah model pembelajaran kooperatif tipe artikulasi. Model pembelajaran pembelajaran artikulasi ini baik digunakan dalam rangka meningkatkan daya ingat dan daya serap peserta didik dalam memahami konsep-konsep materi yang telah diajarkan kepadanya. Konsep model pembelajaran pembelajaran tematik yang dipelajari di SMP 20 terutama pada mata pelajaran IPS adalah konsep pembelajaran terpadu. Konsep pembelajaran terpadu diungkapkan dengan penggunaan terintegrasi. Dan model pembelajaran yang tepat di gunakan untuk meningkatkan pemahaman konsep adalah model pembelajaran kooperatif tife artikulasi. Dari latar belakang di atas, penulis mengambil judul Peningkatan Hasil Belajar Daring Mata Pelajaran IPS Melalui Model pembelajaran Artikulasi Pada Peserta Didik SMP 20 Kota Semarang.

Berdasarkan rumusan masalah di atas, tujuan penelitian ini sebagai berikut:

1. Untuk mengetahui aktivitas guru dengan menerapkan model pembelajaran artikulasi pada hasil belajar daring mata pelajaran IPS materi mengenal negara negara Asean peserta didik kelas VIII SMP 20 kota Semarang

2. Untuk mengetahui aktivitas siswa dengan menerapkan model pembelajaran artikulasi pada hasil belajar daring mata pelajaran IPS materi mengenal negara negara Asean

\section{KAJIAN PUSTAKA}

Pengertian Model pembelajaran Artikulasi Wina Sanjana,(2009-125) model pembelajaran adalah seluruh rangkaian penyajian materi ajar yang meliputi segala aspek sebelum, sedang, dan sesudah pembelajaran yang dilakukan guru, serta fasilitas yang terkait yang digunakan secara langsung atau tidak langsung dalam proses pembelajaran. Para ahli menyatakan bahwa setiap model pembelajaran mengarahkan kita ke dalam mendesain pembelajaran untuk membantu peserta didik sedemikian rupa sehingga tujuan pembelajaran tercapai. Jadi yang dimaksud dengan model pembelajaran adalah rencana atau rangkaian penyajian materi ajar meliputi aspek sebelum, sedang, dan sesudah pembelajaran yang dilakukan guru untuk membantu peserta didik mencapai tujuan pembelajaran.

Menurut Benyamin S. Bloom dalam Anni (2006: 7-12) terdapat 3 ranah belajar, yaitu ranah kognitif, afektif dan psikomotorik. Model pembelajaran artikulasi adalah model pembelajaran dengan sintaks: penyampaian kompetensi, sajian materi, bentuk kelompok berpasangan sebangku, salah satu siswa menyampaikan materi yang baru diterima kepada pasangannya kemudian bergantian, presentasi di depan hasil diskusinya, guru membimbing siswa untuk menyimpulkan. 
Ciri dari model pembelajaran ini adalah seperti pesan berantai yaitu materi yang sudah disampaikan siswa wajib menyampaikan materi tersebut kepada teman siswa satu kelompoknya, kelompoknya dibuat berpasang-pasangan tidak boleh lebih dari dua orang, semua siswa memiliki peran ganda yaitu sebagai penyampai pesan dan penerima pesan.

Model pembelajaran artikulasi dapat meningkatkan konsentrasi dan penyerapan materi pelajaran siswa dalam proses pembelajaran karena setiap siswa dituntut memiliki peran ganda sebagai penyampai pesan dan penerima pesan untuk itu siswa harus memperhatikan dan menyerap penjelasan materi dari guru sebaik mungkin agar dapat menerima materi dengan baik. Model pembelajaran artikulasi berarti menggali kembali materi yang telah dijelaskan oleh guru sebelumnya. Oleh karena itu, dua orang siswa mengulangi kembali apa yang telah dijelaskan guru secara bergantian. Yang satu jadi pendengar dan mencatat yang dikatakan temannya, sementara yang satu lagi menerangkan keterangan guruyang ia simak pada waktu guru menjelaskan pelajarannya tadi, begitu juga sebaliknya.

Dengan demikian, penekanan utama dari model pembelajaran artikulasi ini adalah pengulangan kembali makna pembelajaran yang disampaikan kepada siswa oleh siswa itu sendiri. Model pembelajaran artikulasi ini baik digunakan dalam rangka meningkatkan daya ingat dan daya serap siswa dalam memahami materi yang telah diajarkan kepadanya. Model pembelajaran artikulasi dapat merangsan rasa ingin tahu peserta didik. Model pembelajaran ini dapat membangkitakan keingintahuan peserta didik dengan meningkatkatkan kepercayaan diri siswa untuk bertanya. Teknik ini dapat merangsang rasa ingin tahu peserta didik melalui wawancara.

Perbedaan model artikulasi dengan model pembelajaran yang lain adalah penekanannya pada komunikasi siswa kepada teman satu pasanganya. Pada model artikulasi ada kegiatan wawancara/ menyimak pada teman satu pasanganya. Istarani (2012) Setiap anak memiliki kesempatan untuk menyampaikan pendapat. Model artikulasi adalah model pembelajaran yang menekankan pada aspek komunikasi kelompok.

Setiap model pembelajaran memiliki maksud dan tujuan yang akan dicapai masing-masing, begitu juga model pembelajaran artikulasi. Menurut Ras Eko model pembelajaran artikulasi memiliki tujuan untuk membantu siswa dalam cara mengungkapkan kata-kata dengan jelas dalam mengembangkan pengetahuan, pemahaman serta kemampuan yang dimiliki sehingga siswa dapat membuat suatu keterhubungan antara materi dengan disiplin ilmu.8 Penerapan model artikulasi dalam pembelajaran dimaksudkan untuk melatih siswa dalam menyampaikan ide atau pengetahuannya, menggali informasi berdasarkan kegiatan interaktif.

Ras Eko Boeddy (2011-124) Setiap model pembelajaran memiliki manfaat masing-masing sesuai karakteristik model itu sendiri. Manfaat penerapan model artikulasi pada pembelajaran, khususnya yang berdampak pada siswa adalah sebagai berikut:

a. Siswa menjadi lebih mandiri.

b. Siswa bekerja dalam kelompok untuk menuntaskan materi belajar.

c. Penghargaan lebih berorientasi pada kelompok daripada individu.

d. Terjadi interaksi antarsiswa dalam kelompok kecil. 
e. Terjadi interaksi antarkelompok kecil.

f. Masing masing siswa memiliki kesempatan berbicara atau tampil di depan kelas untuk menyampaikan hasil diskusi kelompok mereka. Berdasarkan manfaat model artikulasi yang sudah diapaparkan tersebut, dapat disimpulkan bahwa model artikulasi ini menekankan pada interaksi dan komunikasi siswa sebagai perekam informasi dari siswa lain sebagai anggota kelompok kecil untuk kemudian menjadi sumber pengetahuan. Siswa secara mandiri menggali informasi dari temannya, kemudian mencernanya, lalu apa yang telah diperoleh tersebut dishare di depan kelas sebagai bentuk pelaporan sekaligus sumber informasi bagi siswa lainnya. Hal ini dapat melatih kemandirian, komunikasi, pemahaman, serta kepercayaan diri siswa dalam pembelajaran

Setiap model pembelajaran memiliki prosedur pelaksanaan sesuai karakteristik dari model pembelajaran itu sendiri. Begitu juga dengan model pembelajaran artikulasi. Model pembelajaran pasti memiliki tujuan yang akan dicapai, maka dari itu pada pelaksanaan model pembelajaran terdapat usaha-usaha serta strategi untuk mencapai tujuan tersebut. Terkait dengan pelaksanaan model pembelajaran, pasti memiliki kelebihan-kelebihan dari model pembelajaran tersebut, begitu juga pada model artikulasi. Kelebihan- kelebihan tersebut tidak jarang dibarengi dengan adanya kelemahankelemahan yang muncul ketika diterapkan pada pembelajaran. Berikut ini adalah kelebihan maupun kekurangan dari metode artikulasi. Kelebihan dan kekurangan model Artikulasi adalah sebagai berikut:

\section{Kelebihan Model Artikulasi}

1) Dapat meningkatkan eksperisi siswa dalam menyajikan materi pelajaran karena ia mengulangi dari apa yang telah dikatakan guru.

2) Dapat lebik mempertajamdaya ingat siswa tentang pelajaran tersebut.

3) Dapat menyalurkan aspirasi siswa ketika menerangkan kembali materi yang diajarka guru kepadanya.

4) Melibatkan siswa secara lasngsung dalam mengakaji dan menggali materi ajar yang telah disampaikan guru.

5) Semua siswa terlibat (mendapat peran)

6) Melatih kesiapan siswa

7) Melatih daya serap pemahaman dari orang lain

8) Cocok untuk tugas sederhana

9) Interaksi lebih mudah

10) Lebih mudah dan cepat membentuknya

11) Meningkatkan partisipasi anak

Kekurangn Model Artikulasi

1) Sulit dipantau apakah siswa mengulangi yang dijelaskan sebelumnya sesuai dengan yang diinginkan 
2) Pembelajaran menjadi gaduh, karena banyak peserta yang berbicara sekaligus

3) Bagi siswa pendiam, sulit rasanya mengikuti model pembelajaran seperti ini.

4) Untuk mata pelajaran tertentu

5) Waktu yang dibutuhkan banyak

6) Materi yang didapat sedikit

7) Banyak kelompok yang melapor dan perlu dimonitor

Model pembelajaran artikulasi merupakan model yang melibatkan peran serta semua anggota kelompok sehingga setiap siswa secara aktif berpartisipasi mengembangakan pengetahuan individu. Interaksi antar individu dapat melatih kepercayaan diri siswa sehingga siswa lebih siap secara mandiri menyerap dan memahami materi yang disampaikan rekan satu kelompoknya. Adapun materi Penelitian Mata Pelajaran IPS

\section{Mengenal Negara-Negara ASEAN}

ASEAN (Association of South East Asian Nations) merupakan organisasi yang beranggotakan negara-negara di Asia Tenggara. ASEAN berdiri pada 8 Agustus 1967 di Bangkok, Thailand. ASEAN diprakarsai lima negara, yaitu Indonesia, Malaysia, Filipina, Singapura, dan Thailand. Saat ini, ASEAN beranggotakan 10 negara, yaitu Indonesia, Malaysia, Filipina, Singapura, Thailand, Brunei Darussalam, Vietnam, Laos, Myanmar, dan Kamboja. Letak geografis dan letak koordinat negara-negara ASEAN tersebut ditunjukkan pada gambar berikut.

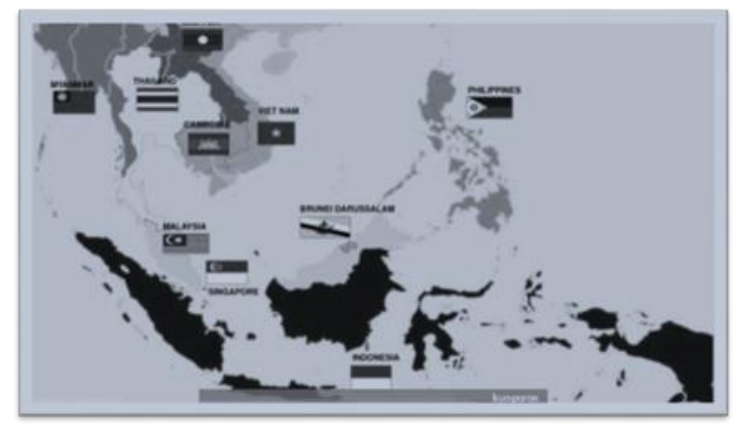

Gambar 1. Peta ASEAN

Untuk memberikan pengertian tentang hasil belajar maka akan diuraikan terlebih dahulu dari segi bahasa. Pengertian ini terdiri dari dua kata 'hasil' dan 'belajar'. Dalam KBBI hasil memiliki beberapa arti: 1) Sesuatu yang diadakan oleh usaha, 2) pendapatan; perolehan; buah. Sedangkan belajar adalah perubahan tingkah laku atau tanggapan yang disebabkan oleh pengalaman.

Secara umum Abdurrahman menjelaskan bahwa hasil belajar adalah kemampuan yang diperoleh anak setelah melalui kegiatan belajar.menurutnya juga anak-anak yang berhasil dalam belajar ialah berhasil mencapai tujuan-tujuan pembelajaran atau tujuan instruksional.

Adapun yang dimaksud dengan belajar Menurut Usman adalah "Perubahan tingkah laku pada diri individu berkat adanya interaksi antara satu individu dengan individu lainnya dan antara individu dengan lingkungan".3 Lebih luas lagi Subrata mendefenisikan belajar adalah "(1) membawa kepada 
perubahan, (2) Bahwa perubahan itu pada pokoknya adalah didapatkanya kecakapan baru, (3) Bahwa perubahan itu terjadi karena usaha dengan sengaj".

Dari beberapa defenisi di atas terlihat para ahli menggunakan istilah "perubahan" yang berarti setelah seseorang belajar akan mengalami perubahan. Untuk lebih memperjelas Mardianto memberikan kesimpulan tentang pengertian belajar:

a. Belajar adalah suatu usaha, yang berarti perbuatan yang dilakukan secara sungguh-sungguh, sistematis, dengan mendayagunakan semua potensi yang dimiliki, baik fisik maupun mental.

b. Belajar bertujuan untuk mengadakan perubahan di dalam driri antara lain perubahan tingkah laku diharapkan kearah positif dan kedepan.

c. Belajar juga bertujuan untuk mengadakan perubahan sikap, dari sikap negatif menjadi positif, dari sikap tidak hormat menjadi hormat dan lain sebagainya.

d. Belajar juga bertujuan mengadakan perubahan kebiasaan dari kebiasaan buruk, menjadi kebiasaan baik. Kebiasaan buruk yang dirubah tersebut untuk menjadi bekal hidup seseorang agar ia dapat membedakan mana yang dianggap baik di tengah-tengah masyarakat untuk dihindari dan mana pula yang harus dipelihara.

e. Belajar bertujuan mengadakan perubahan pengetahuan tentang berbagai bidang ilmu, misalnya tidak tahu membaca menjadi tahu membaca, tidak dapat menulis jadi dapat menulis. Tidak dapat berhitung menjadi tahu berhitung dan lain sebagainya.

f. Belajar dapat mengadakan perubahan dalam hal keterampilan, misalnya keterampilan bidang olah raga, bidang kesenian, bidang tekhnik dan sebagainya.

Hasil belajar merupakan kemampuan yang diperoleh individu setelah proses belajar berlangsung, yang dapat memberikan perubahan tingkah laku baik pengetahuan, pemahaman, sikap dan keterampilan siswa sehingga menjadi lebih baik dari sebelumnya.Hasil belajar merupakan salah satu indikator dari proses belajar. Hasil belajar adalah perubahan perilaku uyang diperoleh siswa setelah mengalami aktivitas belajar. Salah satu indikator tercapai atau tidaknya suatu proses pembelajaran adalah dengan melihat hasil belajar yang dicapai oleh siswa

Hasil belajar merupakan tingkat penguasaan yang dicapai oleh siswa dalam mengikuti program belajar mengajar, sesuai dengan tujuan yang ditetapkan. Menurut Dimyati dan Mudjiono, Dapat dipahami bahwa yang dimaksud dengan hasil belajar merupakan suatu proses untuk melihat sejauh mana siswa dapat menguasai pembelajaran setelah mengikuti kegiatan proses belajar mengajar, atau keberhasilan yang dicapai seorang peserta didik setelah mengikuti kegiatan pembelajaran yang ditandai dengan bentuk angka, huruf, atau simbol tertentu yang disepakati oleh pihak penyelenggara pendidikan.

Dari beberapa teori di atas tentang pengertian hasil belajar, maka hasil belajar yang dimaksud dalam penelitian ini adalah hasil belajar (perubahan tingkah laku: kognitif, afektif dan psikomotorik) setelah selesai melaksanakan proses pembelajaran.dengan strategi pembelajaran information search dan metode resitasi yang dibuktikan dengan hasil evaluasi berupa nilai. 
Faktor-faktor yang Mempengaruhi Hasil Belajar Berhasil atau tidaknya seseorang dalam belajar disebabkan beberapa faktor yang mempengaruhi pencapaian hasil belajar yaitu yang berasal dari dalam peserta didik yang belajar (faktor internal) dan ada pula yang berasal dari luar peserta didik yang belajar (faktor eksternal).

\section{METODE PENELITIAN}

Rancangan penelitian yang digunakan dalam penelitian ini adalah penelitian tindakan kelas (PTK) atau Classroom Action Research dengan kajian berdaur ulang yang terdiri dari empat tahapan yaitu perencanaan, tindakan, observasi, dan refleksi, lebih jelasnya digambarkan sebagai berikut. Berdasarkan alur di atas maka hal pertama yang harus dilakukan adalah merencanakan proses belajar mengajar, melakukan tindakan pembelajaran, mengamati tindakan yang dilakukan, dan terahir adalah merefleksikan hasil pembelajaran sehingga dapat melakukan perencanaan yang lebih matang. Subyek Penelitian ini dilakukan di SMP 20 Kota Semarang Kelas VIII C pada semester genap tahun pembelajaran 2020/2021 yang berjumlah 32 Peserta Didik.

Tahapan per-Siklus Menurut Sukardi (2003: 210) Penelitian Tindakan Kelas adalah penelitian yang dilakukan guru di dalam kelasnya sendiri melalui refleksi diri dengan tujuan untuk memperbaiki mutu praktik pembelajaran di kelasnya. Bentuk penelitian ini yang dilakukan adalah Penelitian Tindakan Kelas (PTK) dengan jenis kolaboratif yang melibatkan guru lain sebagai observer. Pada pelaksanaan penelitian tindakan kelas ini menggunakan dua siklus yakni siklus 1 (pertama) dan siklus II (kedua). Selanjutnya dilakukan ulangan harian 1 dan 2. Dari hasil pengamatan dan refleksi pada siklus 1 diadakan perbaikan/pemantapan pada proses pembelajaran pada siklus II.

\section{HASIL DAN PEMBAHASAN}

Peningkatan hasil belajar sebelum dilakukan tindakan dan setelah dilakukan tindakan pada siklus I. Nilai rata-rata dan persentase ketuntasan belajar meningkat dari data awal yaitu $6.25 \%$ menjadi 31.25. Jumlah peserta didik tuntas pada pra siklus adalah 2 dengan 30 peserta didik yang tidak tuntas, sedangkan pada siklus I jumlah peserta didik tuntas adalah 10 dengan peserta didik tidak tuntas 22. Dengan demikian dapat disimpulkan bahwa pada siklus I hasil belajar pelajaran mengenal Negara asean dengan menggunakan model pembelajaran artikulasi belum memenuhi kriteria ketuntasan klasikal yang telah ditetapkan yaitu $80 \%$ peserta didik tuntas belajar.

Tahapan pengamatan, peneliti mengamati proses pembelajaran yang berlangsung dan mencatat temuan-temuan yang ada pada lembar pengamatan yang telah tersedia. Ada tiga aspek yang peneliti amati dalam proses pembelajaran IPS dengan menggunakan model artikulasi yaitu peserta didik, guru.

Pada saat pelaksanaan siklus I, secara umum proses dengan menggunakan model artikulasi pada materi Negara negara asean sudah berjalan dengan baik. Semua peserta didik kelas VIII hadir dalam pembelajaran daring melalui media sosial pada siklus I. Keaktivan peserta didik dalam pembelajaran IPS dengan menggunakan model artikulasi lebih meningkat dibandingkan dengan pembelajaran IPS dengan menggunakan metode ceramah. Model artikulasi dalam pembelajaran IPS materi menggenal Negara Negara asean bahwasanya peserta didik berdiskusi dengan menggunakan computer atau 
gagged hal ini merupakan hal baru dalam pembelajaran pada masa pandemi. Model arkulasi ini sangat menyenangkan bagi peserta didik karena kegiatan pembelajaran ini bisa mengurangi kebosanan dalam rutinitas keseharian. Peserta didik dapat melakukan tanya jawab dengan teman diskusinya dan merumuskan atau menyimpulkan materi yang diberikan guru melalui situs youtube. Peserta didik dapat mencermati materi karena materi tersebut dapat di downloud dan diputar berkali kali sesuai dengan kebutuhan masing masing.

Pada siklus pertama peserta didik kurang dalam memberikan tanggapan materi khususnya dalam mempertahankan pendapat. Hal ini kemungkinan besar peserta didik belum memahami aturan mainnya pada model artikulas. Peserta didik aktif dengan kelompoknya masing masing dan masih banyak yang kurang serius dalam mengikuti pembelajaran ini.

Pelaksanaan siklus II didasarkan pada siklus Sebelum proses pembelajaran pada siklus II dimulai, guru mengoreksi kekurangan yang ada pada siklus I. Proses pembelajaran pada siklus II, guru lebih berusaha untuk memotivasi peserta didik agar lebih aktif dalam proses pembelajaran maupun dalam proses diskusi berlangsung, guru juga berusaha untuk mengelola waktu dengan baik agar sesuai dengan rencana perbaikan pembelajaran.

Diharapkan dalam pelaksanaan siklus II suasana pembelajaran tidak kaku dan sehingga keaktivan peserta didik, kerjasama dalam kelompok maupun hasil belajarnya meningkat. Dalam tahap perencanaan guru melakukan berbagai langkah langkah yaitu guru menyusun scenario pembelajaran yang berupa rencana perbaikan pembelajaran, guru juga merancang kisi-kisi soal evaluasi dan soal evaluasi untuk mengukur keberhasilan belajar peserta didik dalam pembelajaran IPS dengan menggunakan model pembelajaran artikulasi.

Lembar pengamatan aktivitas peserta didik dalam pembelajaran dan lembar pengamatan aktivitas guru dalam proses pembelajaran serta lembar pengamatan situasi dan kondisi kelas disusun untuk menunjang pelaksanaan pmbelajaran dengan menggunakan model pembelajaran artikulasi. Lembar pengamatan untuk aktivitas peserta didik, aktivitas guru, dan situasi dan kondisi kelas diberi penjelasan mengenai kriteria penilaian untuk memudahkan penilaian oleh observer. Proses pembelajaran pada siklus II lebih ditekankan kepada peserta didik agar lebih fokus mendengarkan penjelasan materi yang disampaikan oleh guru dan lebih aktif dalam proses pembelajaran dan aktif bekerjasama selama diskusi berlangsung.

\section{PEMBAHASAN}

Pembahasan dalam penelitian tindakan kelas ini didasarkan pada hasil pengamatan yang dilanjutkan dengan hasil evaluasi dan refleksi. Secara umum pembelajaran yang berlangsung pada setiap akhir siklus dapat berjalan dengan baik. Keseluruhan tahap-tahap yang dilaksanakan dalam pembelajaran dengan menggunakan model pembelajaran artikulasi dapat dilaksanakan dengan baik, meskipun belum sempurna. Proses pembelajaran daring yang berlangsung dalam dua siklus selalu mengalami peningkatan, baik dari hasil belajar peserta didik maupun keaktivan peserta didik, aktivitas guru selama proses pembelajaran berlangsung. 
Berdasarkan hasil pengamatan dan refleksi pada siklus I dapat diketahui bahwa pelaksanaan pembelajaran dengan model pembelajaran artikulasi belum dapat berjalan secara optimal. Hal ini ditunjukkkan pada perolehan nilai rata-rata peserta didik hanya mencapai nilai 31,6\%. Aktivitas belajar peserta didik yang kurang maksimal disebabkan karena beberapa hal, diantaranya (1) peserta didik terbiasa dengan suasana pembelajaran tatap muka yang terpusat oleh guru mengakibatkan peserta didik kurang aktif dalam proses pembelajaran dan pembelajaran daring mengutamakan sinyal dari perangkat seluler (2) peserta didik belum terbiasa dengan model pembelajaran artikulasi dimana mereka berdiskusi dengan melihat materi melalui video yang diunduh dari laman youtube ; (3) peserta didik belum optimal dalam menganalisis masalah, peserta didik belum fokus saat guru memberikan penjelasan materi, sehingga guru perlu melibatkan peserta didik dalam pembelajaran. Selama pelaksanaan siklus I ada sebagian peserta didik yang merasa senang dengan penggunaan model pembelajaran artikulasi. Hal ini dapat ditunjukkan pada aspek banyaknya peserta didik yang antusias mengikuti pelajaran ditandai rasa senang, sungguh-sungguh dan bertanggung jawab terhadap tugasnya meskipun tidak semua peserta didik merasa tertarik dan senang, sehingga keinginan peneliti diterapkannya model pembelajaran artikulasi untuk pelajaran IPS dengan materi mengenal Negara Negara asean belum sepenuhnya mencapai $80 \%$ dari kriteria ketuntasan peserta didik yang ditargetkan.

Guru dalam melaksanakan pembelajaran IPS dengan materi mengenal Negara Negara asean dengan model pembelajaran artikulasi secara umum sudah baik. Namun, masih terdapat kekurangan dan kelemahan yang harus diperbaiki diantaranya guru/peneliti belum bisa mengkondisikan dalam membimbing kelompok diskusi kurang merata. Guru/peneliti dalam pembuatan media pembelajaran waktu materi terlalu lama durasinya hal ini sangat berpengaruh dalam proses downloud sehingga pada siklus I yang kurang optimal ini berdampak pada hasil belajar peserta didik.

Berdasarkan hasil tes yang dilaksanakan pada akhir siklus I diperoleh nilai rata-rata sebesar $67 \%$ dengan ketuntasan belajar klasikal hanya mencapai 31,1\%, dan terdapat 10 peserta didik yang tuntas belajar dan 22 peserta didik yang belum tuntas belajar. Ada peningkatan dibanding sebelum dilaksanakan pembelajaran dengan model pembelajaran artikulasi, nilai rata-rata kelas meningkat sebesar $13 \%$, dengan persentase ketuntasan klasikal yang mengalami kenaikkan sebesar 25\%, akan tetapi ketuntasan belajar pada siklus I belum tercapai, karena ketuntasan belajar klasikal pada siklus I hanya mencapai $67 \%$ masih jauh dari standar $85 \%$ peserta didik yang memperoleh nilai lebih dari atau sama dengan 67, sehingga siklus I ini perlu diadakan perbaikan pada siklus II.

Berdasarkan hasil tes yang dilaksanakan pada akhir siklus II diperoleh nilai rata-rata sebesar 86,25\% dengan ketuntasan belajar klasikal sebesar 96,8\%. Data hasil belajar tersebut diatas telah membuktikan bahwa model pembelajaran artikulasi efektif dalam meningkatkan hasil belajar peserta didik danmeningkatkan keberanian peserta didik dalam bertanya kritis. Peserta didik dituntut untuk lebih aktif dalam proses pembelajaran. Minat belajar yang tinggi akan menumbuhkan keaktivan peserta didik dalam proses pembelajaran yang pada akhirnya akan berpengaruh terhadap peningkatan hasil belajar peserta didik. 
Model pembelajaran artikulasi melalui daring dapat memberikan kontribusi hasil belajar yang lebih baik sebab dalam anggota kelompok tersebut terjadi interaksi tatap muka dengan teman intrakelompok dan antar kelompok yang berbeda sehingga memunculkan keberanian peserta didik untuk tampil percaya diri. Adanya kerja sama dalam kelompok belajar dengan saling membantu dan saling bertukar pikiran akan membuat pembelajaran IPS dengan materi mengenal negara negara asean menjadi menyenangkan dan akan meningkatkan sikap keterampilan sosial peserta didik.

Hasil belajar peserta didik dengan menggunakan model pembelajaran artikulasi dari nilai ratarata kelas dan ketuntasan klasikal dari sebelum penelitian, siklus I dan siklus II dapat dituliskan dalam bentuk tabel sebagai berikut :

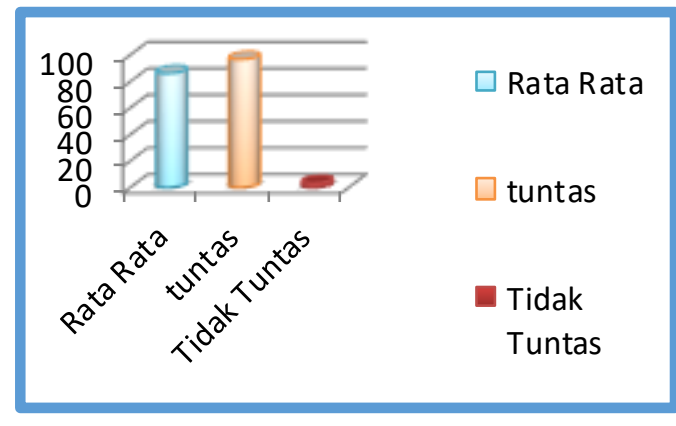

\section{PENUTUP}

\section{Simpulan}

Berdasarkan hasil penelitian dan pembahasan maka dapat disimpulkan bahwa PTK dengan judul peningkatan hasil belajar daring mata pelajaran IPS melalui model pembelajaran artikulasi pada peserta didik SMP 20 Negeri Kota Semarang. Adapun kesimpulannya sebagai berikut :

1. Peningkatan hasil belajar daring mata pelajaran IPS melalui model pembelajaran artikulasi pada peserta didik SMP 20 Negeri Kota Semarang, mengalami kenaikan rata rata nilai dari siklus I 67 $\%$, dan pada siklus II rata rata nilai evaluasi sebesar $86,25 \%$ sehingga penelitian ini dianggap berhasil karena ketetapan ketuntasan peneliti adalah 80 .

2. Peningkatan hasil belajar daring mata pelajaran IPS melalui model pembelajaran artikulasi dapat meningkatkan aktivitas kerjasama peserta didik pada peserta didik SMP 20 Negeri Kota Semarang.

\section{Saran}

Berdasarkan kesimpulan dan hasil penelitian, maka peneliti mengajukan beberapa saran yang yaitu :

1. Peningkatan hasil belajar daring mata pelajaran IPS melalui model pembelajaran artikulasi pada peserta didik SMP 20 Negeri Kota Semarang dapat digunakan pada pembelajaran IPS

2. Penerapan model artikulasi pada pembelajaran daring dapat diterapkan pada materi pembelajaran lainnya.

3. Bagi penelitian lanjutan, penelitian tindakan sekolah untuk meningkatkan hasil belajar peserta didik hendaknya dapat memperluas cakupan aspek yang terdapat dalam penelitian ini.

4. Dalam pelaksanaan PTK, kerjasama antara teman sebaya dan peserta didik dapat meningkatkan hasil yang diharapkan dalam penelitian ini 


\section{DAFTAR PUSTAKA}

Arikunto, S. 2006. Metode Penelitian Kualitatif. Jakarta: Bumi Aksara

Anas, Sudijono. (2009) Pengantar Statistik Pendidikan. Jakarta: Rajawali Pres.

Daryanto. (2001). Evaluasi Pendidikan. Jakarta: Renaka Cifta.

Kasmadi, Hartono. 1996. Model-model dalam Pengajaran Sejarah. Semarang: Ikip Semarang Press.

Kumandar. (2012). Langkah-langkah Mudah Penelitian Tindakan Kelas Sebagai Pengembangan Propesi. Jakarta: Rajawali Pres.

Mulyani, Sumantri. (1988). Kurikulum dan Pengajaran. Jakarta: Depdikbud.

Mustain. (2003). Model Pembelajaran. Bandung: Alumni.

Ngalim, Purwanto. (1997). Prinsip-Prinsip dan Teknik Evaluasi Pengajaran. Bandung : PT. Remaja Rosdakarya

Norhasanah. (2011). Pengertian Pembelajaran Kooperatif Tipe Artikulasi.Medan: Media Persada.

Sadjaah, Edja.(2003) Layanan dan Latihan Artikulasi Anak Tunarungu, (Bandung: San Grafika,

Istarani. (2012). 58 Model Pembelajaran Inovatif. Medan : Media Persada.

Ras Eko Boeddy,(2011) Model Pembelajaran Artikulasi. (Yogya: Graha Ilmu,),

Wina Sanjana, Strategi Pembelajaran Beriontasi Standar Proses Pendidikan,(Jakarta Prenada Group,2009) 